University of Nebraska - Lincoln

DigitalCommons@University of Nebraska - Lincoln

7-26-2019

\title{
Reproductive ecology and movement of pallid sturgeon in the upper Missouri River, Montana
}

Luke M. Holmquist

Christopher S. Guy

Anne Tews

David J. Trimpe

Molly A.H. Webb

Follow this and additional works at: https://digitalcommons.unl.edu/usfwspubs

This Article is brought to you for free and open access by the US Fish \& Wildlife Service at

DigitalCommons@University of Nebraska - Lincoln. It has been accepted for inclusion in US Fish \& Wildlife Publications by an authorized administrator of DigitalCommons@University of Nebraska - Lincoln. 


\title{
Reproductive ecology and movement of pallid sturgeon in the upper Missouri River, Montana
}

\author{
Luke M. Holmquist $^{1}$ (D) | Christopher S. Guy ${ }^{2}$ (D) | Anne Tews ${ }^{3}$ | David J. Trimpe ${ }^{4}$ | \\ Molly A. H. Webb ${ }^{5}$
}

${ }^{1}$ Montana Fish, Wildlife and

Parks, Lewistown Area Resource Office, 205

West Aztec, Lewistown, MT 59457, USA

${ }^{2}$ U.S. Geological Survey, Montana

Cooperative Fishery Research Unit,

Department of Ecology, Montana State

University, Bozeman, Montana

${ }^{3}$ Montana Fish, Wildlife and

Parks, Lewistown Area Resource Office,

Lewistown, Montana

${ }^{4}$ Bureau of Reclamation, Montana Area

Office, Billings, Montana

${ }^{5}$ U.S. Fish and Wildlife Service, Bozeman

Fish Technology Center, Bozeman, Montana

\section{Correspondence}

Luke M. Holmquist, Montana Fish, Wildlife and Parks, Lewistown Area Resource Office, 205 West Aztec, Lewistown, MT 59457, USA.

Email: Iholmquist@mt.gov

Funding information

United States Bureau of Reclamation

\begin{abstract}
Successful recruitment of endangered pallid sturgeon has not been documented in the upper Missouri River basin for decades, and research on the reproductive ecology of pallid sturgeon has been hindered by low sample size. A conservation propagation program was initiated in the 1990s, and the oldest age class of hatchery-origin pallid sturgeon are becoming sexually mature increasing the number of reproductively-active fish in the system. However, it is currently unknown how the reproductive ecology of hatchery-origin pallid sturgeon relates to the few remaining wild fish. Following spring reproductive assessments, weekly relocations were recorded for each individual from late-May to mid-July to facilitate comparisons of spawning season movements among reproductive classifications and between spring hydrographs (2015 and 2016) for male pallid sturgeon. Mean total movement distances ( $\pm S E$ ) were 104.5 km (18.9) for reproductively-active wild males, 116.0 km (18.1) for reproductively-active 1997-year class males, and 20.6 km (3.0) for non-reproductively-active fish of unconfirmed sex. Movement characteristics of reproductively-active males did not differ between 2015 and 2016 despite a difference of eight days in the timing of peak discharge and a difference of $79 \mathrm{~m}^{3} / \mathrm{s}(16.7 \%)$ in magnitude. Male aggregations were observed on the descending limb of the hydrograph in 2016 during temperatures suitable for spawning, but female pallid sturgeon underwent follicular atresia, similar to the other years of the study. Hatchery-origin pallid sturgeon from the conservation propagation program appear to have retained reproductive characteristics from the wild broodstock, a key finding for a population where local extirpation of the wild stock is imminent.
\end{abstract}

\section{1 | INTRODUCTION}

Sturgeons are one of the most imperiled groups of fishes on the planet, largely due to habitat loss, loss of connectivity, and overharvest (Billard \& Locointre, 2001; Birstein, 1993; Haxton \& Cano, 2016). Degradation of habitat and fragmented riverine ecosystems have prevented many sturgeon species from successfully completing their life cycle (Billard \& Locointre, 2001; Haxton \& Cano, 2016). As a conservation measure many populations of sturgeons around the world have been supplemented with hatchery-reared fish (Billard \& Locointre, 2001; Birstein, Bemis, \& Waldman, 1997). The most fundamental questions associated with artificial supplementation is related to the performance of the hatchery fish in the wild (Ireland, Beamesderfer, Paragamian, Wakkinen, \& Siple, 2002). That is, "will the hatchery fish behave like wild fish, reproduce, and ultimately contribute to the recovery of the species".

Pallid sturgeon are well adapted to living in the large, freeflowing, turbid, and warm-water habitats historically found in the 
Missouri and Mississippi river basins (Jordan et al., 2016). However, habitat alterations due to the construction of large dams in the Missouri River have inhibited successful recruitment by pallid sturgeon in the upper Missouri River basin, which resulted in the species being listed as endangered in 1990. The original Recovery Plan for pallid sturgeon prioritized the development of a propagation plan for stocking throughout their native range to augment wild populations with no known natural recruitment (Dryer \& Sandvol, 1993). Stocking of hatchery-origin pallid sturgeon in the upper Missouri River above Fort Peck Reservoir (Recovery Priority Management Area 1 [RPMA1]; also classified as the Great Plains Management Unit [GPMU; USFWS, 2014]) began in 1998 (1997 year class) with 732 age-1 pallid sturgeon (Gerrity, Guy, \& Gardner, 2008). The stocking program began with the goal of hatchery-origin pallid sturgeon acclimating to the riverine environment, maturing, and ultimately contributing to successful recruitment and recovery of the species (Dryer \& Sandvol, 1993).

Previous research concluded that the 1997 year class of pallid sturgeon had acclimated to the conditions present in the upper Missouri River (Gerrity et al., 2008). More recently, the hatchery-origin pallid sturgeon in RPMA1 are becoming sexually mature (Talbott \& Webb, 2014a), and it is important to compare the reproductive ecology of the hatchery-origin fish to wild pallid sturgeon before the remaining wild individuals are extirpated. A successful conservation propagation program produces fish that retain the characteristics from the wild broodstock and contribute to recovery of the species (Ireland et al., 2002). In the lower Missouri River, hatchery-origin female pallid sturgeon were reported to have spawned, providing evidence that the hatchery-origin fish are capable of spawning in the wild (DeLonay et al., 2009). Spawning events have been well documented for wild fish in RPMA2 (the Yellowstone and Missouri rivers below Fort Peck; DeLonay et al., 2016; Fuller, Jaeger, \& Webb, 2008) but have not been confirmed in RPMA1. Thus, there is a need to resample reproductively-active female pallid sturgeon (i.e., hatchery-origin and wild) following the putative spawning season to determine ovulatory success in RPMA1. Furthermore, the presence of male aggregations have been used by researchers to identify spawning sites weeks prior to spawning activity in the Yellowstone River (DeLonay et al., 2016) but have not previously been described for pallid sturgeon in RPMA1.

The purpose of this study was to document and compare the reproductive ecology of pallid sturgeon under two different spring discharge hydrographs and between reproductively-active hatcheryorigin and reproductively-active wild fish. The specific objectives were to: (a) compare physiological and movement characteristics among reproductively-active hatchery-origin, reproductively-active wild, and non-reproductively-active unconfirmed sex hatchery-origin pallid sturgeon (i.e., sex and stage of maturity not confirmed but confirmed to be non-reproductive); (b) compare movement between varying spring hydrographs for reproductively-active pallid sturgeon (wild and hatchery-origin); (c) identify sites where males aggregate during the spawning season, and 4) determine the ovulatory success of wild and hatchery-origin female pallid sturgeon in the upper Missouri River.

\section{2 | STUDY AREA}

The study area was the Missouri River upstream from Fort Peck Reservoir to the Marias River confluence (river kilometers 3,0103,303; Figure 1), which was designated as Recovery-Priority Management Area 1 (RPMA1) in the original pallid sturgeon recovery plan (Dryer \& Sandvol, 1993), but now is part of the larger GPMU (USFWS, 2014). In addition to Fort Peck Reservoir blocking

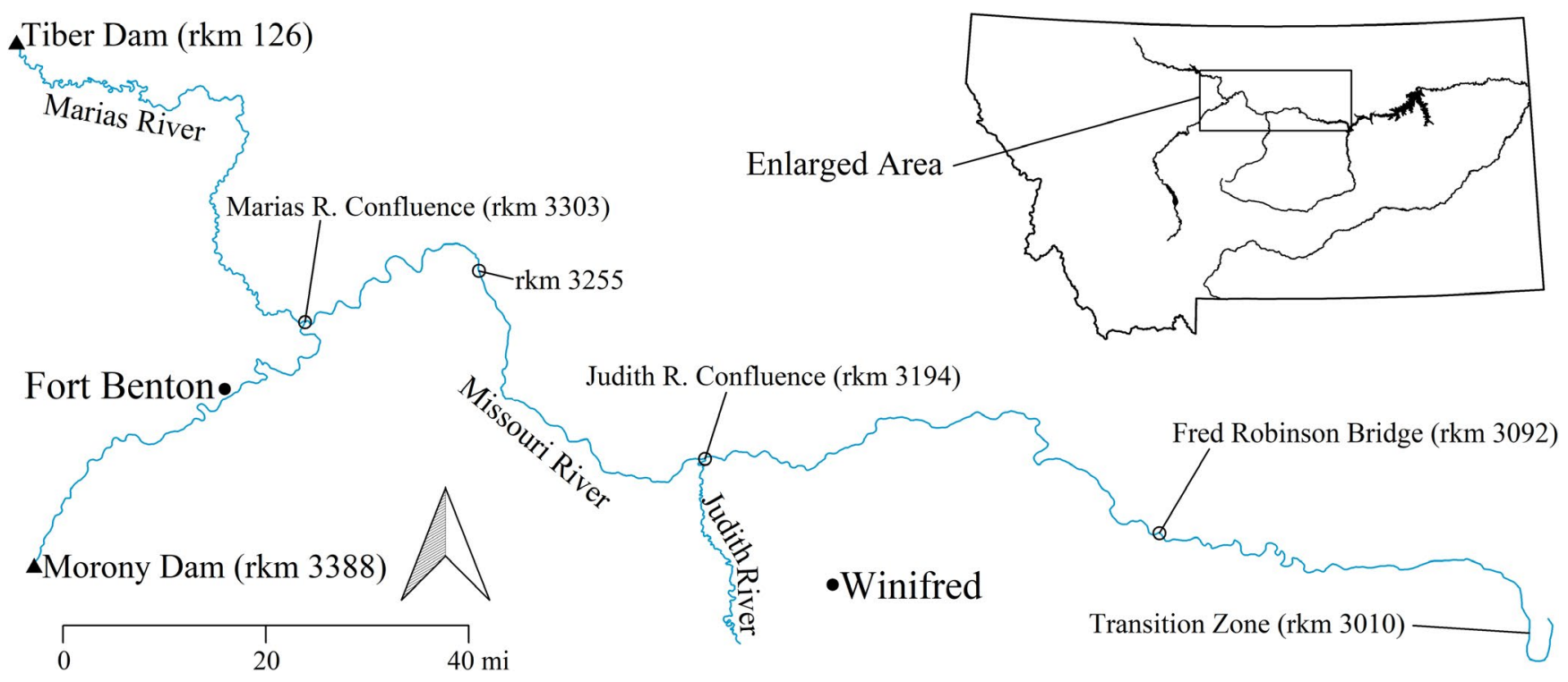

FIGURE 1 Map of the upper Missouri River upstream of Fort Peck Reservoir, Montana. River kilometer (rkm) denoted in parentheses for each point-of-interest 
downstream movement, several dams have been constructed upstream of RPMA1 and influence the conditions downstream. Discharge in the Missouri River is regulated upstream of the study area by Canyon Ferry Dam ( $r k m ~ 3,626)$, and the Marias River discharge is regulated by Tiber Dam (129 km upstream of the confluence with the Missouri River) near Chester, Montana. Morony Dam, located $380 \mathrm{~km}$ upstream from the headwaters of Fort Peck Reservoir, is the most downstream of several dams near Great Falls, Montana. In addition to Morony Dam, four other dams near Great Falls, Montana, are also operated as run-of-river projects with outflows approximately equal to inflows (S. Leathe, NorthWestern Energy, personal communication), thus they have little influence on the hydrograph.

\section{3 | MATERIALS AND METHODS}

\section{1 | Fish sampling and handling}

Hatchery-origin and wild pallid sturgeon were sampled or resampled from April thru June of 2015 and 2016 for radio-tagging, biological sample collection, or both. Biological information included blood, gonadal tissue, length, and weight. Pallid sturgeon were sampled and handled using the handling protocol developed for pallid sturgeon (USFWS, 2012). Pallid sturgeon were sampled by drifting $45.7-\mathrm{m}$ long and $1.8-\mathrm{m}$ deep trammel nets with $5.08-\mathrm{cm}$ inner bar mesh and 25.4-cm outer bar mesh panels. Once captured, pallid sturgeon were scanned for a Passive Integrated Transponder (PIT) tag and examined for elastomer or missing scutes to confirm the individual as a 1997 year class fish and then were weighed $( \pm 1 \mathrm{~g})$ and measured (FL, $\pm 1 \mathrm{~mm}$ ). When initially captured, pallid sturgeon without transmitters were biopsied to determine sex and stage of maturity (techniques described below), and a Lotek Wireless MCFT2-3A transmitter was implanted using techniques described in Holmquist (2017).

\section{2 | Assigning reproductive classifications}

Sturgeon species are not sexually dimorphic; thus, several tools (minor biopsy, ultrasound, endoscopy, and blood plasma sex steroid concentrations) have been developed to determine sex and stage of maturity (Webb, Van Eenennaam, Crossman, \& Chapman, 2018). Pallid sturgeon were assigned to reproductive classifications based on sex (male [M], female [F], or unconfirmed [U]), maturity (reproductively-active [RA] or non-reproductively-active [NRA]), and origin (hatchery-origin [HO] or wild [W])). The reproductive classifications were: non-reproductively-active unconfirmed sex hatchery-origin (NRAUHO), reproductively-active male hatcheryorigin (RAMHO), non-reproductively-active male hatchery-origin (NRAMHO), reproductively-active female hatchery-origin female (RAFHO), non-reproductively-active female hatchery-origin (NRAFHO), reproductively-active male wild (RAMW), reproductively-active female wild (RAFW), and non-reproductively-active female wild (NRAFW) pallid sturgeon. In a given year, the sex steroid concentrations for all NRA classifications of pallid sturgeon were below concentrations that would indicate that they were RA that season, but NRAUHO were fish that had not previously been confirmed to be sexually mature.

Sex steroid (testosterone $[T]$ and estradiol-17 $\beta$ [E2]) concentrations in blood plasma were measured by radioimmunoassay (RIA) to determine sex, stage of maturity, and ovulatory success when combined with other techniques (Webb \& Doroshov, 2011). In the field, blood samples were collected from the caudal vasculature using a $2 \mathrm{ml}$ syringe and processed according to the protocol described in Webb et al. (2018). Frozen plasma samples were stored at -20 to $-80^{\circ} \mathrm{C}$ prior to analysis in the lab. In the laboratory, steroids $T$ and E2 were extracted from thawed plasma following the method of Fitzpatrick, Van Der Kraak, and Schreck (1986). Recovery efficiencies for all steroids were determined by adding tritiated steroids to tubes containing plasma $(N=4)$. All steroid assay results were corrected for recovery. Plasma concentrations of $T$ and E2 were measured by RIA as described in Fitzpatrick et al. (1986) and modified by Feist, Schreck, Fitzpatrick, and Redding (1990). All samples were analyzed in duplicate. The intra- and inter-assay coefficients of variation for all assays was $<5 \%$ and $10 \%$, respectively. Steroid levels were validated by verifying that serial dilutions were parallel to standard curves. Concentrations of $T>40 \mathrm{ng} / \mathrm{ml}$ with no detectable E2 are indicative of reproductively-active pallid sturgeon males (Webb, Maskill, \& Halvorson, 2016). Concentrations of $T>10 \mathrm{ng} / \mathrm{ml}$ and $E 2>1 \mathrm{ng} / \mathrm{ml}$ are indicative of reproductively-active females (Talbott \& Webb, 2014b). These concentrations were used to discriminate among classes of sex and stage of maturity in conjunction with gonadal tissue samples, ultrasound, and endoscopy.

In addition to blood plasma sex steroid analysis, gonadal biopsies were collected after visual examination of the gonads to determine sex, stage of maturity, and spawning readiness (Webb et al., 2018). Ovarian follicles were collected from ripe females for macroscopic analysis and calculation of oocyte Polarization Index (PI) in the laboratory. The PI was used to assess spawning readiness (Talbott et al., 2011). For newly captured females, gonadal tissue was collected prior to the insertion of the radio-transmitter, and the sample was preserved in $10 \%$ phosphate-buffered formalin. Females that were previously radio-tagged and were suspected to be ripe were sampled using the minimally invasive technique described by Candrl, Papoulias, and Tillitt (2010).

When an incision was made but the gonads were not visible to the unaided eye, an endoscope or otoscope was used. The endoscope (Vividia 2.0) was only used in 2016, and images were recorded for further inspection at a later time. This technique was used in an attempt to identify the sex of non-reproductive individuals that had not yet reached sexual maturity as well as providing information to pair with RIA results for higher certainty in assigning fish to reproductive classifications (Webb et al., 2018). Because some individuals were tagged prior to this study and multiple field crews aided in performing surgeries, visual confirmation of sex was not always achieved and most often was inconclusive. Fish were classified as NRAUHO pallid sturgeon when sex steroid concentrations were below the concentrations indicative of reproductively-active male and female pallid sturgeon and there was no visual confirmation 
of sex or previous samples showing that sexual maturity had been reached.

\section{3 | Tracking}

Weekly tracking was initiated mid- to late-May (following recapture effort) and continued until mid-July when water temperatures exceeded the thermal maximum for larval survival $\left(24^{\circ} \mathrm{C}\right.$; Kappenman, Webb, \& Greenwood, 2013) or when the last ripe individual was determined to have spawned or became atretic (techniques described below). Individuals were located once per week by tracking the entire study area. Fish locations were identified using two Lotek SRX 400 telemetry receivers (Lotek Wireless, Inc.). The two receivers were used in tandem to located fish as described in Holmquist (2017) which facilitated relocations to be made within $6 \mathrm{~m}$ of the true fish location (based on blind tests of transmitters placed in the river). In addition to mobile tracking, an array of 14 solar powered land-based telemetry stations with data logging Lotek SRX 400 receivers were used to passively monitor movement throughout the study area.

\subsection{Discharge and temperature}

Spring discharge and temperature regimes recorded the Landusky USGS (06115200) gauging station were used to describe differences in discharge regimes between years. The highest discharge from May 1 through mid-July was determined to be the peak spring discharge. Movement data were analyzed for all locations collected on the ascending and descending limb of the hydrograph until water temperatures reached $24^{\circ} \mathrm{C}$ for three consecutive days and is hereafter referred to as the putative spawning season. Locations obtained after the $24^{\circ} \mathrm{C}$ threshold were not included in the analysis of movement for the putative spawning season but were included in the analysis of movement rates and Multi-Distance Spatial Cluster Analysis.

\section{5 | Movement}

Data collected in 2015 and 2016 was used for movement comparisons between reproductive classifications and flow regimes. Total movement $(\mathrm{km})$ and maximum upstream location $(\mathrm{rkm})$ were calculated for each fish during the putative spawning season and compared among reproductive classifications and between spring hydrographs (also compared home range size [km]). Weekly total movement rates $(\mathrm{km} / \mathrm{w})$, weekly net movement rates $(\mathrm{km} / \mathrm{w})$, and maximum upstream locations ( $\mathrm{rkm}$ ) were compared among weeks in response to weekly patterns in discharge and temperature. Total movement was calculated by summing all distances moved between sequential locations. Home range was calculated as the distance $(\mathrm{km})$ between the most upstream and most downstream location for an individual fish. Net weekly movement rates $(\mathrm{km} / \mathrm{w})$ were calculated as the difference in rkm for successive weekly relocations divided by the duration of time between locations such that positive rates indicate upstream movement and negative rates indicate downstream movement, and rates were then converted to the appropriate time interval that was reflective of data collection. Total movement rates were calculated as the distance $(\mathrm{km})$ between subsequent weekly relocations (expressed as km/week). Maximum upstream location ( $r k m)$ was the most upstream location during the putative spawning season.

\section{6 | Male aggregations}

Summaries of weekly locations, movement rates, and Multi-Distance Spatial Cluster Analysis (described below) for reproductively-active male pallid sturgeon were used to identify male aggregations during the spawning season. Weeks with a small spread of weekly locations ( $\mathrm{rkm})$, net movement rates $(\mathrm{km} / \mathrm{w})$ near zero, and spatial clustering at small distances were identified as male aggregations.

\section{7 | Assessing ovulatory success}

Females were resampled in late June or early July to assess ovulatory success when water temperatures exceeded $24^{\circ} \mathrm{C}$ for three consecutive days or when they exhibited a change in movement behavior (Fuller et al., 2008). Female pallid sturgeon have been observed to decrease in weight by $12-22 \%$ after spawning (Fuller et al., 2008; Webb \& Doroshov, 2011); therefore, significant weight loss relative to pre-spawning weights provided evidence of successful spawning. However, a decrease in weight can also be observed for female sturgeon that have undergone follicular atresia (Webb \& Doroshov, 2011). Consequently, ovarian tissue was collected for visual and histological analysis to determine ovulatory success in females. In addition, blood samples were collected from females at the time of post-spawn assessment. Concentrations of $T$ and $E 2$ have been shown to decrease prior to the detection of macroscopic or histological signs of follicular atresia in sturgeon (Talbott et al., 2011). Using a combination of blood plasma sex steroid concentration changes, body-weight change, and gonadal biopsy allowed for higher certainty when determining spawning success (Webb \& Doroshov, 2011). This was advantageous over assessing spawning success solely from an observed decrease in blood plasma concentrations or weight because atretic females will experience a decrease in plasma steroid concentrations but will maintain at pre-atresia weight for up to two weeks (Webb \& Doroshov, 2011). Ovulatory assessment data included a female that was assessed in 2014 to increase the sample size of RA females.

\section{8 | Data analysis}

Individual pallid sturgeon were the experimental unit for all statistical tests. To reduce the chance of making a type II error, $\alpha=0.1$ was set a priori for all statistical analyses. Due to sample size constraints, statistical analyses only included NRAUHO, RAMHO, and RAMW pallid sturgeon. Normality was assessed using residual and normality plots. Levene's Test for Homogeneity was conducted to test the assumption of equal variances. Analysis of variance (ANOVA) was used to analyze data that met the assumptions of equal variances and normality. Analysis of variance was used to compare mean maximum upstream locations between NRAUHO, RAMHO, and RAMW pallid sturgeon. When the assumptions of 
ANOVA were violated, a Kruskal-Wallis non-parametric analysis of variance was used. Kruskal-Wallis tests were used to compare the distribution of testosterone concentrations and total movement among NRAUHO, RAMHO, and RAMW categories. When conducting post-hoc multiple comparisons for significant KruskalWallis tests, a Bonferroni adjustment of $p$-values was used to control for family-wise error rates. Welch's t-tests were used to compare spawning season total movement, home range size, and maximum upstream location of reproductively-active male pallid sturgeon between 2015 and 2016.

Repeated measures ANOVA was used to compare mean location ( $\mathrm{rkm}$ ) and mean movement rates between wild and hatcheryorigin males, and if no difference was detected, males were pooled to test whether movement rates differed among weeks. Individual pallid sturgeon were the repeated measure. Bonferroni multiplecomparisons test was used to control the family-wise error rate for making multiple comparisons following ANOVAs with significant main effects. Multi-Distance Spatial Cluster Analysis (Ripley's $\mathrm{K}$-function) was used to evaluate clustering and dispersion during specific weeks in 2015 and 2016 for reproductively-active male pallid sturgeon. To assess male aggregations and migration patterns, the results of the weekly analysis of location, movement rates, and Multi-Distance Spatial Cluster Analysis were visually compared to weekly summaries of median daily temperatures, discharges, and changes in discharge between relocations during the weeks and weekly intervals that locations were collected. All statistical analyses were performed using R (R Development Core Team). The Multi-Distance Spatial Cluster Analysis (Ripley's K-function) was conducted using the riverdist package in $\mathrm{R}$ (Tyers, 2016).

\section{4 | RESULTS}

In 2015, 45 pallid sturgeon were sampled with trammel nets. Of the 45 pallid sturgeon, 33 were classified as NRAUHO, three as RAMHO, four as RAMW, two as NRAMHO, and one each as RAFW, RAFHO, and NRAFW. No NRAFHO pallid sturgeon were sampled in 2015. In 2016, 59 pallid sturgeon were sampled with trammel nets. Of the 59 pallid sturgeon, 41 were classified as NRAUHO, eight as RAMHO, six as RAMW, two as RAFHO, and one each as NRAFW and NRAFHO. Zero NRAMHO and RAFW pallid sturgeon were sampled in 2016. Three RAMW pallid sturgeon were removed from the river and were used in the wild broodstock spawning program; therefore, size and steroid concentrations from these fish are included in the analysis to increase sample size, but data for these fish were removed from all movement analysis.

\subsection{Discharge and temperature}

Peak median daily discharge occurred on June 6 in $2015\left(473 \mathrm{~m}^{3} / \mathrm{s}\right.$; $18.4^{\circ} \mathrm{C}$ ) and May 29 in $2016\left(394 \mathrm{~m}^{3} / \mathrm{s} ; 16.9^{\circ} \mathrm{C}\right.$ ) (Figure 2). Duration of peak discharge was brief in both years. In addition, the timing of peak median discharge was 4-11 days earlier than the timing of the peak before the construction of Canyon Ferry Dam (median discharge peak occurred on June 10; 1934-1953), and the peak magnitude was 212 to $291 \mathrm{~m}^{3} / \mathrm{s}$ lower than the median pre-Canyon Ferry Dam magnitude (685 m³ $/ \mathrm{s}$; 1934-1953). Water temperature regimes were similar in both years and provided a pseudo-controlled water temperature regime (Figure 2). Median daily water temperature reached $24^{\circ} \mathrm{C}$ for the third consecutive day on June 30 in 2015 and on July 2 in 2016, marking the end of the suitable spawning period (Figure 2).

\subsection{Hatchery-origin and wild pallid sturgeon}

\subsection{1 $\mid$ Sex steroids}

Testosterone concentrations were lowest for non-reproductivelyactive pallid sturgeon, low for reproductively-active females, and highest for reproductively-active males (Table 1). There was strong evidence that the distribution of $T$ concentrations differed among
FIGURE 2 Spring hydrographs (median daily discharge $\mathrm{m}^{3} / \mathrm{s}$ ) and temperature regime (median daily temperature ${ }^{\circ} \mathrm{C}$ ) for the upper Missouri River in 2015 and 2016. Discharge (solid lines) and temperature (dashed lines) data were recorded at the Landusky USGS guaging station. The horizontal dashed line represents water temperatures exceeding $24^{\circ} \mathrm{C}$

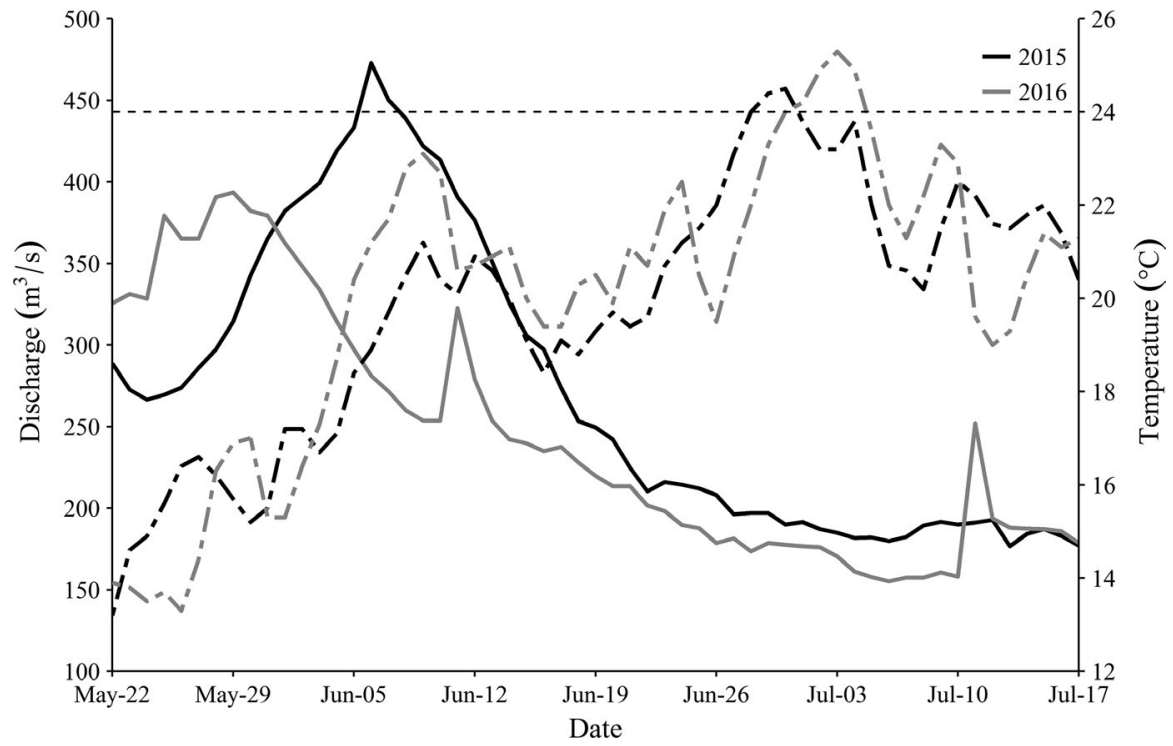




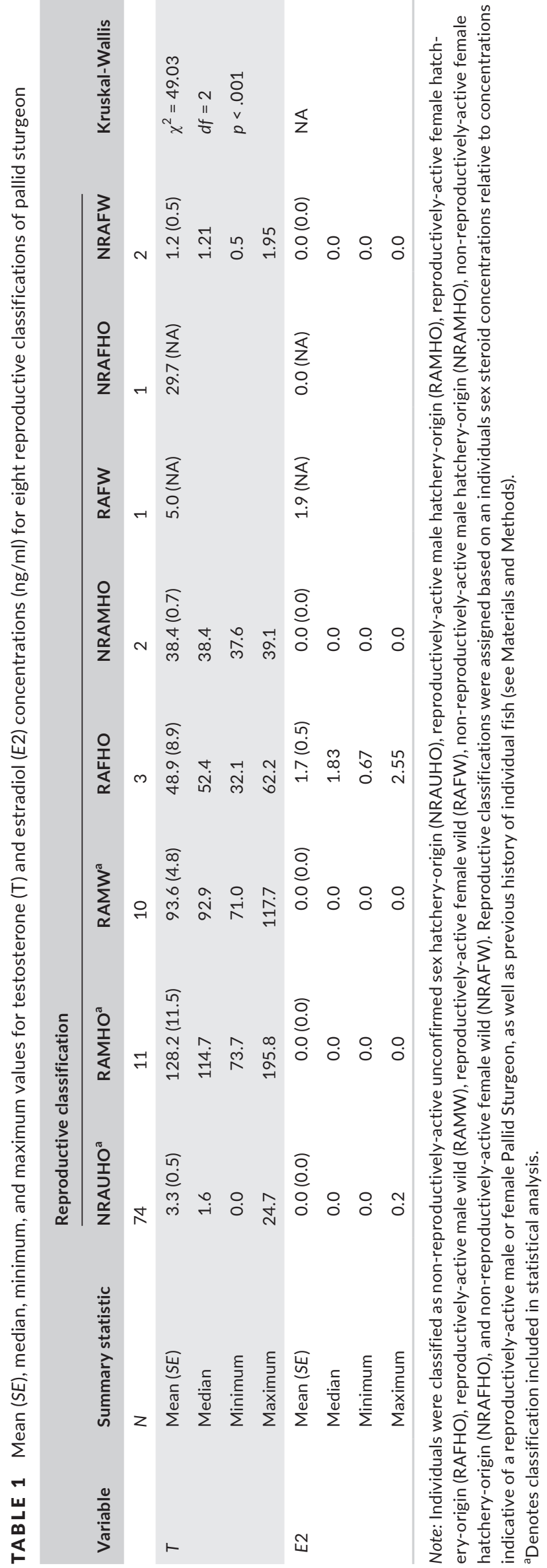

the three reproductive categories, and the distribution of $T$ concentrations differed between NRAUHO and RAMHO pallid sturgeon $(Z=-5.7, p<.001)$, but there was no evidence of a difference between RAMHO and RAMW pallid sturgeon $(Z=0.56, p=.87)$. Estradiol concentrations were non-detectable to low (below predetermined concentrations for maturity) for all NRAUHO, RAMHO, and RAMW pallid sturgeon but were elevated for female pallid sturgeon (Table 1). No statistical tests were conducted because elevated E2 concentrations were only detected in female classifications which had small sample sizes (Table 1).

\subsection{2 | Movement}

Median total movement was higher for reproductively-active classifications than for non-reproductively-active classifications and was similar between RAMHO and RAMW pallid sturgeon (Figure 3). There was strong evidence that the distribution of total movement $(\mathrm{km})$ differed among the three reproductive categories $\left(\chi_{2}^{2}=31.46\right.$, $p<.001)$, where total movement $(\mathrm{km})$ differed between NRAUHO and RAMHO pallid sturgeon $(Z=-4.61, p<.001)$, but did not differ between RAMHO and RAMW pallid sturgeon $(Z=0.07, p=1.0)$. Four NRAUHO pallid sturgeon exhibited large total movements (from 110 to $140 \mathrm{~km}$ ), which were as large as movements made by the reproductively-active fish (Figure 3 ). Total movement distances by reproductively-active pallid sturgeon (with multiple individuals) were more variable than non-reproductively-active classifications.

Mean maximum upstream locations ( $\mathrm{rkm}$ ) were greater for classifications of pallid sturgeon that were confirmed to have reached sexual maturity than for NRAUHO fish (Figure 3). There was strong evidence that the mean maximum upstream location $(\mathrm{km})$ differed among the three reproductive categories $\left(F_{2,87}=9.15, p<.001\right)$, with the mean maximum upstream location $(\mathrm{rkm})$ differing between NRAUHO and RAMHO pallid sturgeon ( $t=3.38, p=.003$ ), but no evidence of a difference between RAMHO and RAMW pallid sturgeon $(t=0.18, p=1.0)$. The mean maximum upstream location of RAMHO pallid sturgeon during the putative spawning season was $48.5 \mathrm{~km}$ (18.9-78.1 km, 90\% Cl) upstream of the mean maximum upstream location of NRAUHO pallid sturgeon. In 2016, a RAFHO female had a maximum upstream location of rkm 3,297.5 (Figure 3) and was the only reproductively-active fish to be relocated more than $245 \mathrm{~km}$ (> rkm 3,255 ) upstream of the reservoir transition zone during the study.

\subsection{Discharge and reproductively-active male spawning movement}

Total movement, home range, median river kilometer, and maximum upstream location ( $\mathrm{rkm}$ ) for reproductively-active males (hatchery-origin and wild pooled) did not differ between 2015 and 2016 (Table 2), despite a difference of eight days in the timing of peak discharge and a difference of $79 \mathrm{~m}^{3} / \mathrm{s}$ in the peak magnitude. Males were pooled because results from the previous section comparing the movement of $\mathrm{HO}$ and wild males demonstrated similar movement between the two classifications during the putative spawning season. 
FIGURE 3 Total movement (km, bottom panel, * denotes mean) and maximum upstream location ( $\mathrm{rkm}$, top panel, ${ }^{*}$ denotes mean) during the putative spawning season for pallid sturgeon tracked in the upper Missouri River by reproductive classification. Individuals were classified as non-reproductivelyactive unconfirmed sex hatchery-origin (NRAUHO), reproductively-active male hatchery-origin (RAMHO), reproductivelyactive female hatchery-origin (RAFHO), reproductively-active male wild (RAMW), reproductively-active female wild (RAFW), non-reproductively-active male hatchery-origin (NRAMHO), nonreproductively-active female hatcheryorigin (NRAFHO), and non-reproductivelyactive female wild (NRAFW). Same letters indicate no significant difference between reproductive classifications

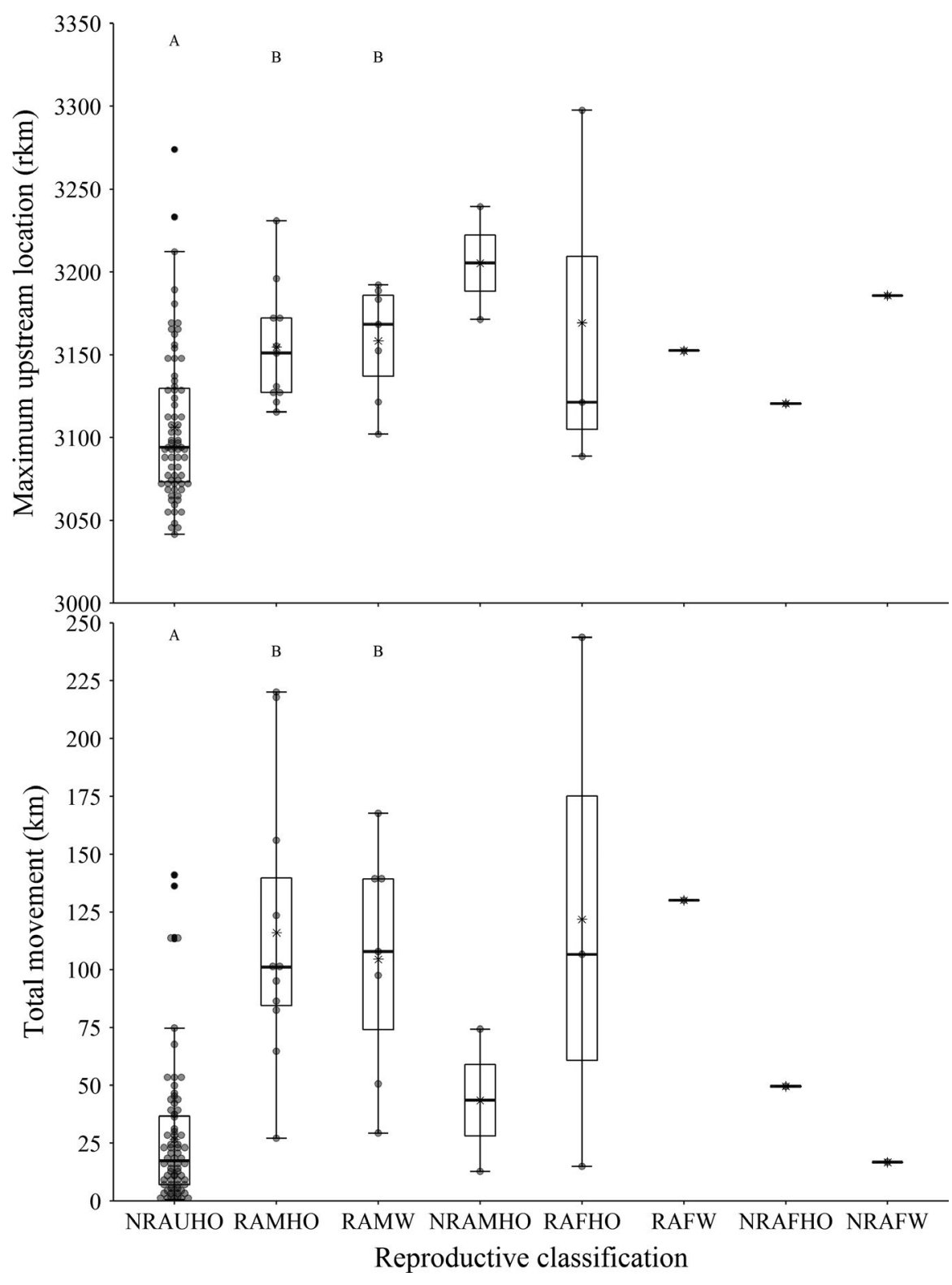

\section{4 | Male aggregations}

\subsubsection{Weekly locations and movement rates}

Mean river kilometer (i.e., location) did not differ between RAMW and RAMHO pallid sturgeon in $2015\left(F_{1,11}=0.49, p=.50\right)$ or in $2016\left(F_{1,9}=0.43, p=.53\right)$, thus males from those two groups were pooled. Reproductively-active male pallid sturgeon progressively moved upstream during the tracking period in 2015 and 2016, with mean locations $(\mathrm{km})$ being furthest downstream during the first two weeks of tracking in both years, within one week of peak discharge (Figure 4). Mean locations ( $\mathrm{rkm}$ ) were most upstream during the last two weeks of the tracking period when discharge was low and water temperature was decreasing (Figure 4). When reproductively-active males were pooled, mean river kilometer differed among weeks in $2015\left(F_{7,39}=2.64, p=.03\right)$ and in 2016 $\left(F_{7,69}=9.14, p<.001\right)$. In 2015 , the spread of reproductively-active male pallid sturgeon locations $(\mathrm{rkm})$ was the smallest in week 2 (June 1-7) when locations varied from rkm 3,069.0 to $3,123.9$ (Figure 4). The spread of reproductively-active male locations was the smallest in week 3 of 2016 (Figure 4), with 8 out of 11 individuals being located between rkm 3,082.2 and 3,093.0.

Male hatchery-origin and wild pallid sturgeon had similar net movement rates within each week. Additionally, when both classifications of males were pooled together, the most rapid downstream (negative) net movement rates were from relocations collected in the early weeks, when discharge was rising or peaked and temperature was rising (Figure 5). In 2016, mean net movement rates were near zero for movement between week 3 and week 4 relocations, with 7 of the 11 male pallid sturgeon moving $<10 \mathrm{~km}$ between weekly locations (Figure 5). Mean net movement rate did not differ between RAMW and RAMHO pallid sturgeon in $2015\left(F_{1,5}=0.07, p=.80\right)$ or in $2016\left(F_{1,9}=0.18, p=.68\right)$, and therefore males were pooled in both years for weekly analysis 


\begin{tabular}{|c|c|c|c|c|}
\hline \multirow[b]{2}{*}{ Variable } & \multirow[b]{2}{*}{ Summary statistic } & \multicolumn{2}{|l|}{ Year } & \multirow[b]{2}{*}{ Welch's T-test } \\
\hline & & 2015 & 2016 & \\
\hline & $N$ & 7 & 11 & \\
\hline \multirow[t]{4}{*}{ Total movement } & Mean (SE) & $115.5(21.7)$ & $109.0(17.0)$ & \multirow{4}{*}{$\begin{array}{l}t_{12.8}=0.23 \\
p=.82\end{array}$} \\
\hline & Median & 107.8 & 101.1 & \\
\hline & Minimum & 50.7 & 27.0 & \\
\hline & Maximum & 220.0 & 217.7 & \\
\hline \multirow[t]{4}{*}{ Home range } & Mean (SE) & $79.6(17.7)$ & $79.3(9.3)$ & \multirow{4}{*}{$\begin{array}{l}t_{9.3}=0.02 \\
p=.97\end{array}$} \\
\hline & Median & 58.7 & 82.1 & \\
\hline & Minimum & 24.8 & 27.0 & \\
\hline & Maximum & 155.5 & 121.3 & \\
\hline \multirow[t]{4}{*}{ Median rkm } & Mean (SE) & $3,131.5(14.8)$ & $3,111.2(9.0)$ & \multirow{4}{*}{$\begin{array}{l}t_{9.6}=1.20 \\
p=.26\end{array}$} \\
\hline & Median & $3,120.3$ & $3,101.7$ & \\
\hline & Minimum & $3,092.3$ & $3,088.8$ & \\
\hline & Maximum & $3,197.6$ & $3,184.5$ & \\
\hline \multirow[t]{4}{*}{ Maximum rkm } & Mean (SE) & $3,159.3(17.0)$ & $3,153.9(8.5)$ & \multirow{4}{*}{$\begin{array}{l}t_{9.0}=0.28 \\
p=.80\end{array}$} \\
\hline & Median & $3,152.4$ & $3,155.4$ & \\
\hline & Minimum & $3,102.0$ & $3,115.5$ & \\
\hline & Maximum & $3,230.9$ & $3,196.0$ & \\
\hline
\end{tabular}

TABLE 2 Mean (SE), median, minimum, and maximum values for total movement $(\mathrm{km})$, home range $(\mathrm{km})$, maximum upstream location (river kilometer [rkm]), and median location ( $\mathrm{rkm}$ ) during the putative spawning season for male pallid sturgeon (hatchery-origin and wild pooled) for 2015 and 2016 of net movement rates (Figure 5). When reproductively-active males were pooled, mean net movement rate did not differ among weekly intervals in $2015\left(F_{6,33}=0.68, p=.66\right)$ but did differ among weekly intervals in $2016\left(F_{6,59}=1.92, p=.09\right.$; Figure 5).

Mean total movement rates were variable among weeks and did not appear to have a relationship with change in discharge or date (photoperiod) for either year (Figure 5). Mean total movement rate did not differ between RAMW and RAMHO pallid sturgeon in $2015\left(F_{1,5}=0.22, p=.65\right)$ or in $2016\left(F_{1,9}=0.27, p=.62\right)$, thus males were pooled for weekly analysis (Figure 5 ). When reproductively-active males were pooled, mean total movement rate differed among weekly intervals in $2015\left(F_{6,33}=3.09, p=.02\right)$ and in $2016\left(F_{6,59}=2.12, p=.06\right)$.

\subsubsection{Multi-distance spatial cluster analysis}

In 2015, reproductively-active male pallid sturgeon locations were statistically determined as clustered (solid line is above the grey $90 \%$ confidence envelope) during weeks 1 and 2 and were statistically dispersed (solid line is outside and below the grey $90 \%$ confidence envelope) in week 3 (Figure 6). Locations of radio-tagged reproductively-active male pallid sturgeon were clustered at the shortest distances in week 2 (2015; Figure 6) during a period of rising/peak discharge (median daily discharge from 382 to $472 \mathrm{~m}^{3} / \mathrm{s}$ ) and increasing temperature (median daily temperature from 16.7 to $19.7^{\circ} \mathrm{C}$ ). The distribution of reproductively-active male pallid sturgeon locations was not different from random in weeks 4 through 8 (2015; Figure 6). In 2016, reproductively-active male pallid sturgeon were strongly spatially clustered in week 3 , with weaker degrees of clustering in weeks $1,4,5$, and 6 , and had strong evidence of spatial dispersion in weeks 7 and 8 (Figure 6). Strong evidence of spatial clustering in week 3 (June 6-12) occurred at shorter distances than expected at random (2016; Figure 6), suggesting that a male aggregation had formed. On June 6 , six reproductively-active males (one wild and five hatchery-origin) were relocated near the Fred Robinson Bridge (between river kilometer 3,091.4 and 3,093.0) when water temperatures varied from 21.7 to $23.0^{\circ} \mathrm{C}$ and median daily discharge was $281.2 \mathrm{~m}^{3} / \mathrm{s}$ (on descending limb). Reproductively-active male locations were dispersed during weeks 7 and 8 (2016; Figure 6) after five consecutive days (June 30 to July 4) where median daily water temperatures exceeded $24^{\circ} \mathrm{C}$.

\section{5 | Ovulatory assessment}

In 2014, one wild female pallid sturgeon was assessed in the spring (May 8) and summer (July 4; Table 3). The oocyte PI decreased from spring to summer (Table 3). Although the female had decreased E2 concentrations from spring to summer, plasma $T$ concentrations were higher in the summer than spring (Table 3). Sex steroid concentrations had not decreased below concentrations indicative of initiation of follicular atresia and body weight changes were not indicative of a post-spawn female. The ripe wild female tracked in 2014 was resampled in the spring of 2015 , and visual inspection of the ovary indicated that atresia had occurred in 2014.

In 2015, two female pallid sturgeon were sampled-one wild and one hatchery-origin (Table 3). The oocyte PI for both females decreased between spring and summer (Table 3 ). The wild female weighed $1.5 \%(250 \mathrm{~g})$ more in the summer than spring, and the hatchery-origin female weighed $5.6 \%$ (380 g) less in summer compared to spring, indicating that neither female had oviposited (Table 3). Both females experienced large decreases in sex steroid concentrations 


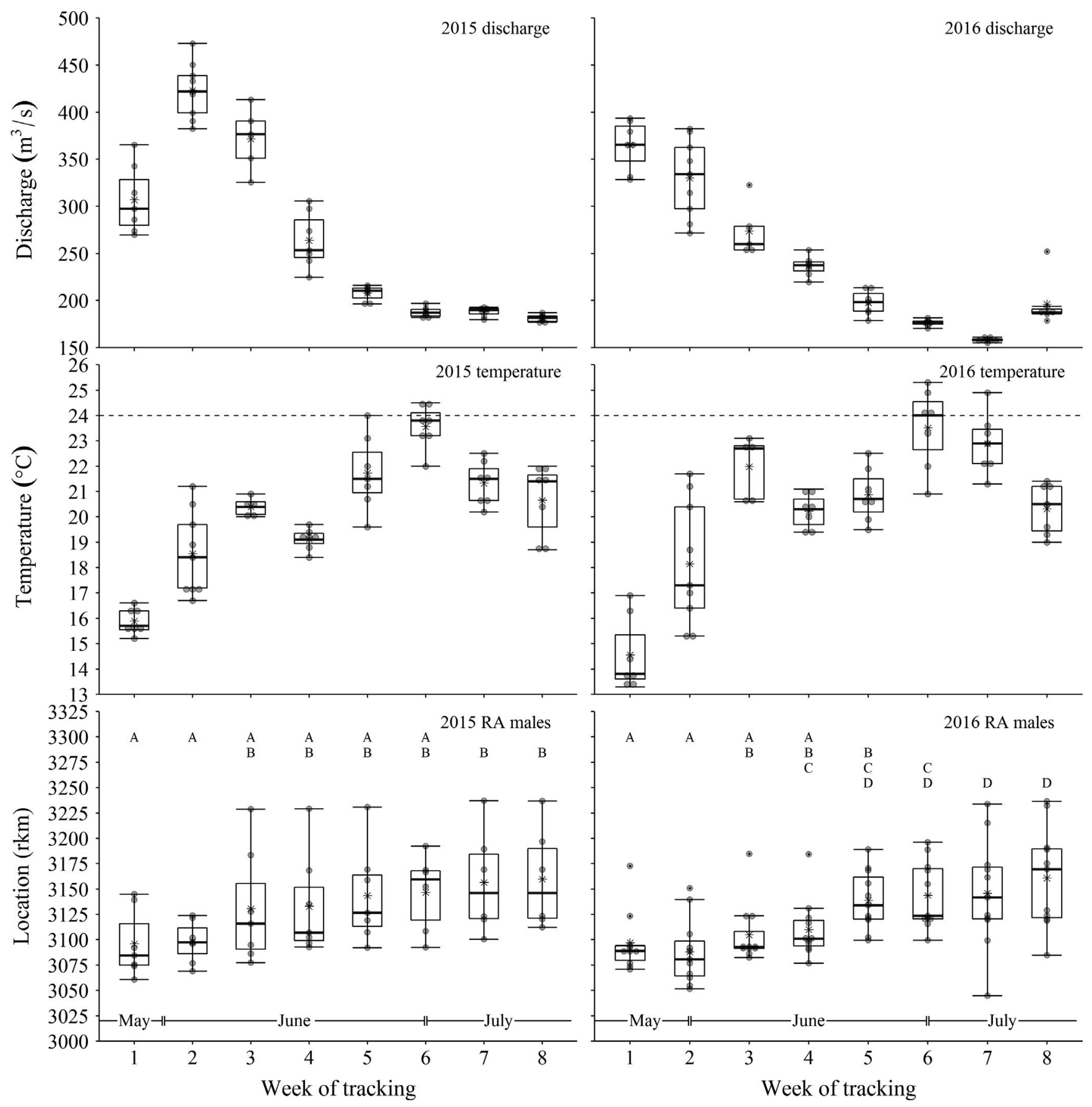

FIG URE 4 Weekly summary of discharge (top panels, ${ }^{*}$ denotes mean), water temperature (middle panels, ${ }^{*}$ denotes mean), and location (rkm [river kilometer], bottom panels, ${ }^{*}$ denotes mean) of reproductively-active male Pallid Sturgeon (wild and hatchery-origin combined) during 2015 (left panels) and 2016 (right panels) in the upper Missouri River, Montana. Discharge and water temperature were summarised from daily median measurements recorded at the Landusky USGS guaging station. Same letters indicate no significant difference between weeks. The horizontal dashed line in the temperature panels represents water temperatures exceeding $24^{\circ} \mathrm{C}$

( $T$ and E2) from spring to summer, providing early indications of the onset of follicular atresia (Table 3).

In 2016, two hatchery-origin female pallid sturgeon were sampled in the spring and again in summer. Female 1 weighed $5.1 \%$ (360 g) less when sampled in the summer compared to the spring, and Female 2 weighed $5.6 \%$ (360 g) less over the same time period, indicating that neither female had oviposited (Table 3). Oocyte PI was not calculated from the summer sample for either female because the follicles were actively undergoing follicular atresia. Female 1 in 2016 was recaptured earlier in the season (June 3) and, interestingly, already had steroidogenic indications of follicular atresia at that time. Both females experienced large decreases in sex steroids to non-detectable concentrations of $T$ and E2 between sampling dates, which provide additional evidence of follicular atresia (Table 3). 


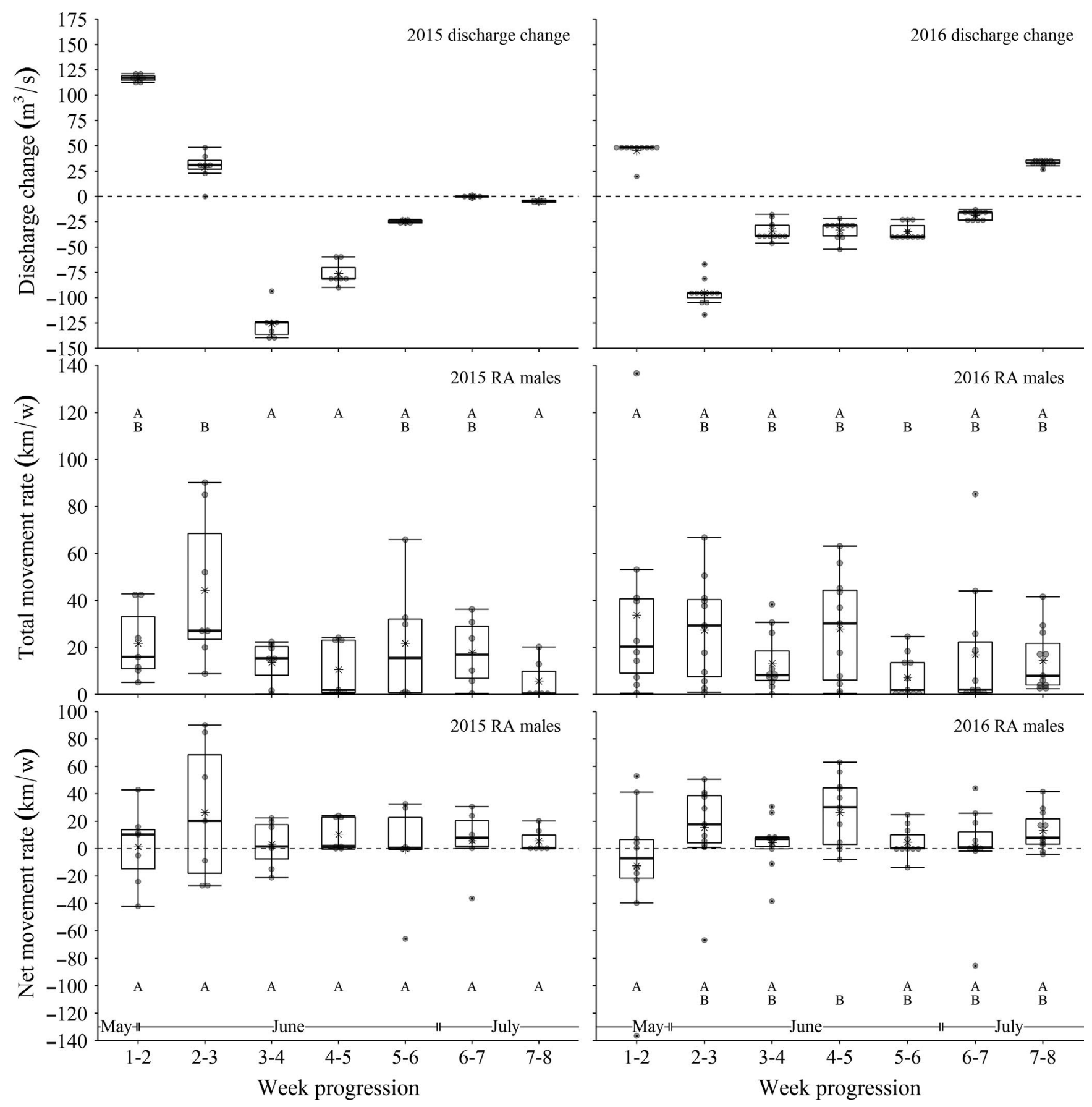

FIGURE 5 Daily median discharge change between weekly relocations for individual fish (top panels, ${ }^{*}$ denotes mean), total movement rate (middle panel, ${ }^{*}$ denotes mean), and net movement rate (bottom panels, ${ }^{*}$ denotes mean) between weekly locations for reproductivelyactive male pallid sturgeon (wild and hatchery-origin pooled) during 2015 (left panels) and 2016 (right panels), in the upper Missouri River, Montana. Change in discharge was the difference in daily median measurements recorded at the Landusky USGS guaging station between two sequential weekly locations for individual fish. Similar letters indicate no significant difference between weeks

\section{DISCUSSION}

In general, RAMHO pallid sturgeon had similar physiological and movement characteristics to RAMW pallid sturgeon but dissimilar to non-reproductively-active pallid sturgeon. Differences in the timing and magnitude of peak spring discharge between years did not result in a change of movement characteristics for reproductively-active male pallid sturgeon (hatchery-origin and wild). Finally, despite potential spawning aggregations of reproductively-active males forming on the descending limb of the hydrograph near Fred Robinson Bridge in 2016 (also in 2014; see Holmquist, 2017), all reproductively-active females experienced follicular atresia.

Reproductively-active hatchery-origin and wild males had similar sex steroid concentrations and spawning season movements. Evaluations 
$\underline{2015}$
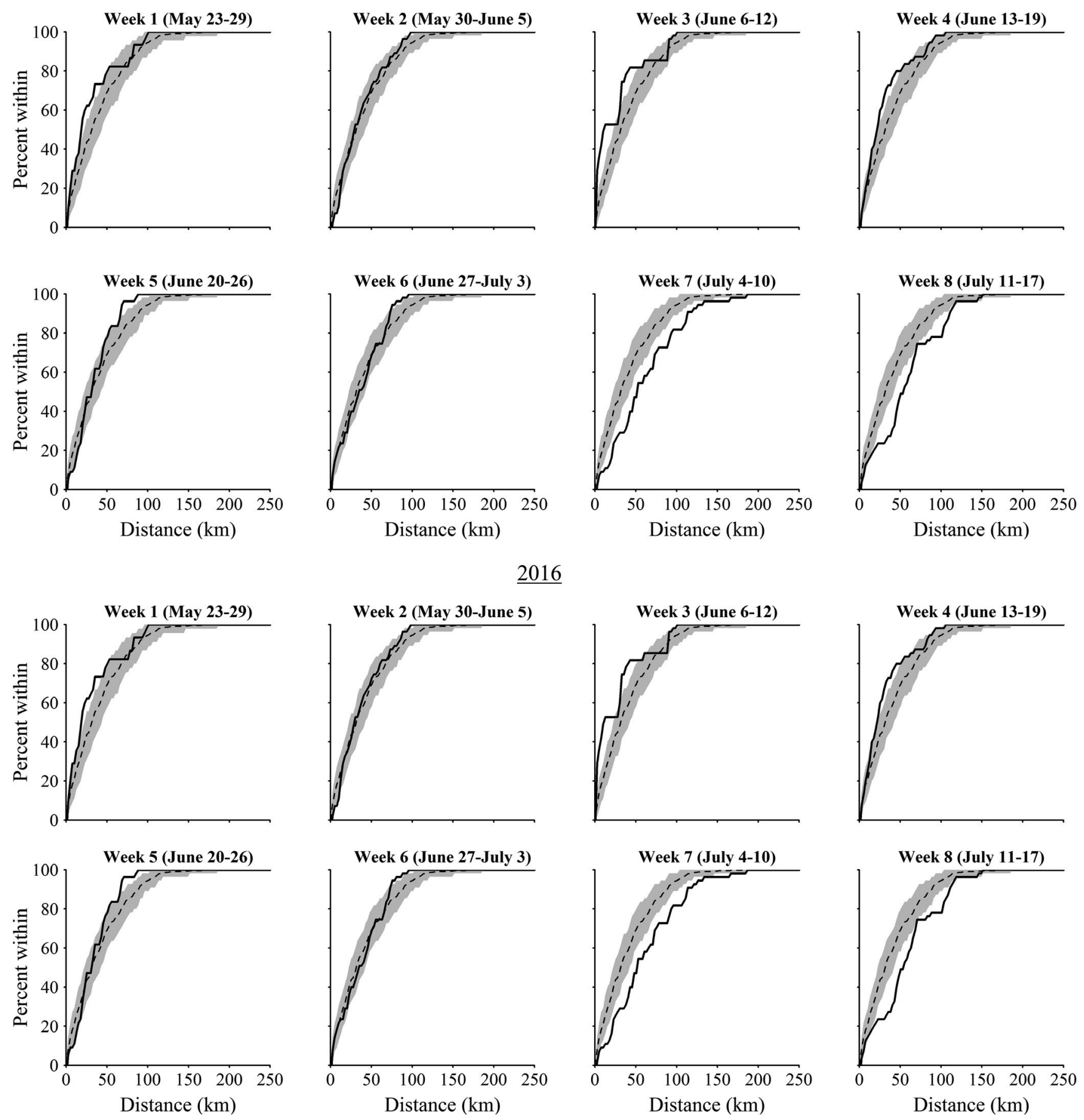

FIG URE 6 Weekly Multi-Distance Spatial Cluster Analysis for reproductively-active male pallid sturgeon (hatchery-origin and wild pooled) in 2015 (top eight panels) and 2016 (bottom eight panels). The solid line is the observed percentage of individuals within a given distance to another individual, the dashed line is the average expected percentage of individuals within a given distance to another individual based on 1,000 random simulations of the weekly relocations, the grey envelope is a $90 \%$ confidence interval of the expected value. Observed values above the confidence envelope represent statistically significant clustering at a given distance, and observed values below the confidence envelope represent statistically significant dispersion

of the performance of hatchery-origin pallid sturgeon in the wild have focused on the movements, habitat-use, or both (Gerrity et al., 2008; Jordan, Klumb, Wanner, \& Stancill, 2006; Richards, 2011) and were either directly compared to wild pallid sturgeon (Richards, 2011) or sympatric shovelnose sturgeon (Gerrity et al., 2008; Richards, 2011), but none of these studies compared confirmed reproductively-active hatchery-origin and wild pallid sturgeon. This study is also among the first studies to quantify and contrast reproductive and movement characteristics between confirmed reproductively-active hatchery-origin and wild fish of any sturgeon species; thus, truly evaluating the influence of origin on 


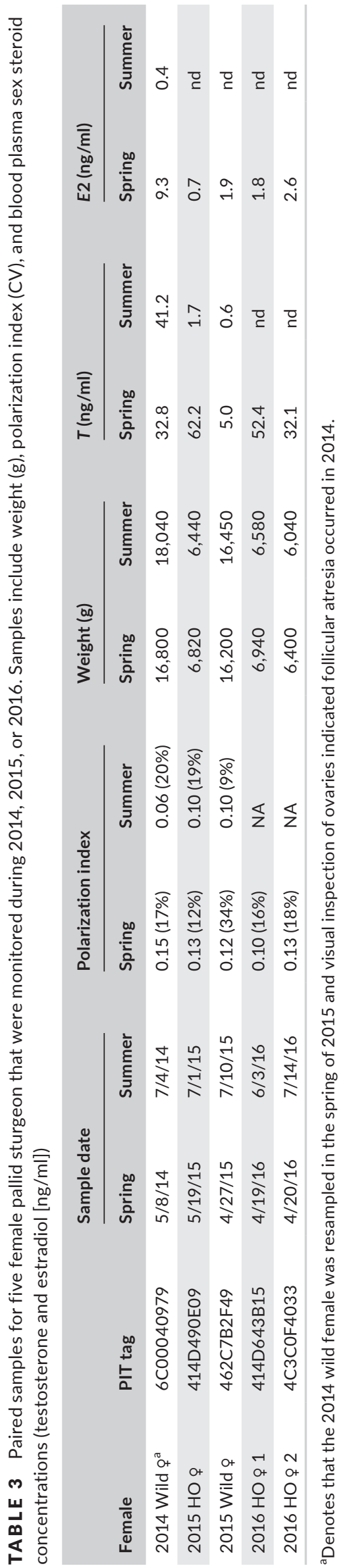

the reproductive ecology of the species. This approach evaluates the efficacy of the pallid sturgeon conservation propagation program. The paucity of such studies in the literature is likely because sturgeon are a late maturing species combined with the relatively short duration of time since the development of conservation propagation programs that have produced and stocked marked individuals.

Reproductive pallid sturgeon exhibited greater movements than non-reproductive fish, similar to what has been shown for shovelnose sturgeon (DeLonay et al., 2009; Richards, Guy, Webb, Gardner, \& Jensen, 2014) and Gulf sturgeon Acipenser oxyrinchus desotoi (Fox, Hightower, \& Parauka, 2000). Migratory behavior of Atlantic sturgeon Acipenser oxyrinchus was also influenced by reproductive status with reproductive fish being located further upstream (Van Eenennaam et al., 1996). All sturgeon species generally have multi-year reproductive cycles (Haxton, Sulak, \& Hildebrand, 2016) and confirming that reproductively-active sturgeon move greater distances than non-reproductively-active sturgeon during the spawning season highlights the need for knowing the reproductive status of all tagged-individuals in movement studies. For example, Richards (2011) found that wild adult pallid sturgeon moved five times greater distances than hatchery-origin juveniles, a similar ratio to what we observed between RAMHO and RAMUHO, however Richards (2011) did not confirm the reproductive status of individuals; thus, unlike this study the differences in movement could not be attributed to spawning. Smaller movements during the putative spawning season by non-reproductive fish is not surprising because the motivation to migrate large distances associated with spawning is absent. Several NRAUHO pallid sturgeon had large total movements, which were more typical for reproductive fish than non-reproductive fish. It is unclear what the stimuli were for such large movement by the NRAUHO pallid sturgeon. It is possible that these individuals were reproductively-active males, but when assessed in the spring, circulating sex steroids were below the concentrations indicative of reproductively-active male or female pallid sturgeon. However, the large total movements exhibited by all four NRAUHO individuals occurred in 2016 and none of them were observed at the male aggregation, providing further evidence (in addition to blood plasma sex steroid concentrations) of a non-spawning motivation for moving large distances.

Spawning season movement characteristics were similar in 2015 and 2016 , despite a difference of $79 \mathrm{~m}^{3} / \mathrm{s}$ in peak magnitude and eight days in the timing of peak discharge. It has been widely hypothesized that there is a link between spring discharge and spawning migrations of Scaphirhynchus spp. (USFWS, 2000, 2003) and that discharge, temperature, and photoperiod cue migration (Papoulias, Delonay, Annis, Wildhaber, \& Tillett, 2011; Webb \& Doroshov, 2011). Interestingly, temperature regimes between the two years were similar, and tracking was conducted over the same time period in both years, which resulted in a pseudo-controlled temperature regime and photoperiod. Unfortunately, the combined effects of low snowpack and needs of stakeholders within the Missouri River basin limited the ability to have large manipulations of spring discharge between years, and the variation in discharge may not have been biologically relevant to pallid sturgeon. Upstream and downstream movement by reproductively-active males was observed during the ascending limb (including 
the week of peak discharge in both years), and the furthest upstream locations were recorded after the putative spawning season, indicating that many male pallid sturgeon moved downstream to spawn and then returned to upper reaches following the spawning season. Peak discharge occurred early in 2015 and 2016 relative to the historical peak discharge resulting in a shorter duration of time when data was collected on the ascending limb of the hydrograph. Additional weeks of tracking during the ascending limb would have allowed more certainty in the conclusion that pallid sturgeon move downstream to spawn, but anecdotal evidence and the upstream locations of reproductive fish during the recapture effort corroborates this conclusion. Pallid sturgeon spawning movements are hypothesized to be cued and occur on the ascending limb of the hydrograph with spawning taking place on the descending limb of the hydrograph (Fuller et al., 2008), which has been documented in the Yellowstone River (DeLonay et al., 2016; Fuller et al., 2008). Pallid sturgeon spawning has not been documented in RPMA1 (i.e., the reach for this study), and the timing of spawning relative to peak discharge is unknown. The observation of downstream spawning migrations differ from what has been suggested to occur in the lower Missouri River (DeLonay et al., 2016) and in the upper Missouri River downstream of Fort Peck Reservoir including the lower Yellowstone River (DeLonay et al., 2016; Fuller et al., 2008). Anadromous sturgeon spp. migrated upstream from the ocean during spawning migrations (shortnose sturgeon Acipenser brevirostrum, Buckley \& Kynard, 1985; Gulf sturgeon, Fox et al., 2000; green sturgeon Acipenser medirostris, Erickson \& Webb, 2007), but white sturgeon in the fragmented upper Columbia River have exhibited downstream movement (Hildebrand, McLeod, \& McKenzie, 1999) similar to the pallid sturgeon in RPMA1. Downstream spawning movement in RPMA1 may have been a behavioral response by pallid sturgeon to the only available suitable spawning habitat occurring downstream of habitat used during the non-spawning season. That is not to say that upstream spawning habitat does not exist and would not be available under a different set of environmental conditions (i.e., elevated tributary flows during the putative spawning season).

Male aggregations formed on the descending limb of the hydrograph during optimal water temperatures $\left(16-20^{\circ} \mathrm{C}\right.$ [Kappenman et al., 2013]), but the presence of a gravid female at the aggregation (near Fred Robinson Bridge) in 2014 (see Holmquist, 2017) and 2016 did not elicit a spawning event (i.e., for radio-tagged females). Only $80 \mathrm{~km}$ (during this study) of free-flowing riverine habitat are available downstream for larval drift downstream of this site; $165 \mathrm{~km}$ less than the minimum distance hypothesized to be needed for survival of drifting pallid sturgeon free embryos (Guy et al., 2015). Male aggregations formed on the descending limb of the hydrograph, which corroborates observations of pallid sturgeon in Yellowstone River (DeLonay et al., 2016; Fuller et al., 2008) and has assisted in identifying where gravid female pallid sturgeon will engage in spawning activity. Male pallid sturgeon also arrive earlier and stay longer at the spawning sites in the Yellowstone River (DeLonay et al., 2016; Fuller et al., 2008) which is similar to what has been described for lake sturgeon (Bruch \& Binkowski, 2002), Gulf sturgeon (Fox et al., 2000), shortnose sturgeon (Buckley \& Kynard, 1985), Atlantic sturgeon (Van Eenennaam et al., 1996), and white sturgeon
(Paragamian \& Kruse, 2001), but the specific timing and duration of spawning appears to be dependent on females and is likely cued by the presence of optimal spawning conditions and the presence of a suitable mate (Webb \& Doroshov, 2011). Water temperature has been suggested as the most likely short-term spawning cue for females to initiate spawning activity (Papoulias et al., 2011; Richards et al., 2014; Wildhaber et al., 2011), but water temperature was within the described spawning temperatures (DeLonay et al., 2016) while females were at the male aggregation, and the females still failed to spawn. This suggests that other necessary short-term spawning cues were lacking.

Spawning failure (atresia) occurred in all RAFHO and RAFW pallid sturgeon, indicating a similar reproductive response for hatchery-origin and wild females to unfavorable spawning conditions; thus, corroborating our finding that the reproductive ecology of wild broodstock have been retained in mature hatchery-origin pallid sturgeon. Follicular atresia being observed in all five females was an unexpected finding-the cause is unknown. Follicular atresia is believed to be a mechanism for long-lived species, such as sturgeon, to cope with unfavorable spawning conditions (Webb \& Doroshov, 2011). Female reproductive cycles take multiple years to complete in sturgeons, and atresia is an adaptation to recycle the energy that went into producing the ovarian follicles into the next cycle rather than spawning during an unfavorable year when the survival of progeny would be low (Valdebenito, Paiva, \& Berland, 2011). Atresia in sturgeon has been shown to be related to elevated water temperatures during ovarian follicle development (Linares-Casenave, Van Eenennaam, \& Doroshov, 2002; Webb et al., 2001), and in other cases, exclusion from suitable spawning habitat by physical barriers (Artyukin, Sukhoparova, \& Fimukhina, 1978; Veshchev \& Noikova, 1983, 1988). Although no experimentally demonstrated link between altered discharge and follicular atresia has been found, there are studies suggesting a minimum discharge threshold for successful spawning for Kootenai River white sturgeon (Paragamian \& Wakkinen, 2002) and shovelnose sturgeon in a Missouri River tributary (Goodman et al., 2013). Additionally, the low density of reproductively active pallid sturgeon in RPMA1 results in a limited number of suitable mates, which could influence spawning success (Papoulias et al., 2011; Webb \& Doroshov, 2011). Portions of the geographic range for pallid sturgeon where spawning has been shown to occur can serve as a comparative template for the conditions that are conducive to spawning relative to the conditions that lead to females undergoing follicular atresia in this study.

In summary, this study is the first to directly compare the reproductive physiology and movement characteristics of reproductivelyactive hatchery-origin pallid sturgeon with wild pallid sturgeon and found that the reproductive ecology is similar between hatchery-origin and wild fish. The minor differences between the hydrographs did not influence spawning related movement and reproductivelyactive pallid sturgeon were rarely observed far enough upstream to provide adequate larval drift distances, in addition to all females undergoing follicular atresia. Hatchery-origin pallid sturgeon retaining characteristics from the wild broodstock is a success for the hatchery program, but conservation propagation programs must be coupled 
with ecosystem restoration to address the cause(s) of recruitment failure (Anders, 1998). Investigating potential management actions for restoring natural recruitment has previously been hindered by a low sample size, but the number of reproductively-active individuals (primarily hatchery-origin) will increase dramatically in the coming years. Future studies on these reproductive hatchery-origin individuals should result in stronger conclusions regarding how environmental conditions and altered habitat characteristics affects natural recruitment of pallid sturgeon.

\section{ACKNOWLEGEMENTS}

Funding for this work was provided by the U.S Bureau of Reclamation. The authors would like to thank all of those who provided assistance in the field or laboratory. We would specifically like to thank Rob Beattie, Jeffery Eshelman, Robert Jensen, Leif Halvorson, Casey Jensen and Michael Schilz for their efforts on this project. The Montana Cooperative Fishery Research Unit is jointly sponsored by the U.S. Geological Survey, Montana Fish, Wildlife \& Parks, Montana State University, and the U.S. Fish and Wildlife Service. Any use of trade, firm, or product names is for descriptive purposes only and does not imply endorsement by the US Government. This study was performed under the auspices of Montana State University institutional animal care and use protocol 2013-48. The findings and conclusions in this article are those of the authors and do not necessarily represent the views of the U.S. Fish and Wildlife Service.

\section{DATA AVAILABILITY STATEMENT}

The data that support the findings of this study are available from the corresponding author upon reasonable request.

\section{ORCID}

Luke M. Holmquist (iD https://orcid.org/0000-0002-9282-8897

Christopher S. Guy iD https://orcid.org/0000-0002-9936-4781

\section{REFERENCES}

Anders, P. J. (1998). Conservation aquaculture and endangered species: Can objective science prevail over risk anxiety? Fisheries, 23(11), 28-31.

Artyukin, E., Sukhoparova, A. D., \& Fimukhina, L. G. (1978). The gonads of the sturgeon, Acipenser guldenstaldt, in the zone below the dam of the Volograd water engineering system. Journal of Ichthyology, 18, 912-923.

Billard, R., \& Locointre, G. (2001). Biology and conservation of sturgeon and paddlefish. Reviews in Fish Biology and Fisheries, 10, 355-392. https://doi.org/10.1023/A:1012231526151

Birstein, V. J. (1993). Sturgeons and paddlefishes: Threatened fishes in need of conservation. Conservation Biology, 773-787, https://doi. org/10.1046/j.1523-1739.1993.740773.x

Birstein, V. J., Bemis, W. E., \& Waldman, J. R. (1997). The threatened status of acipenseriform species: A summary. Environmental Biology of Fishes, 48, 427-435. https://doi.org/10.1007/0-306-46854-9_33
Bruch, R. M., \& Binkowski, F. P. (2002). Spawning behavior of lake sturgeon (Acipenser fulvescens). Journal of Applied Ichthyology, 18, 570579. https://doi.org/10.1046/j.1439-0426.2002.00421.x

Buckley, J., \& Kynard, B. (1985). Habitat use and behavior of pre-spawning and spawning shortnose sturgeon, Acipenser brevirostrum, in the Connecticut River. In F. P. Binkowski, \& S. I. Doroshov (Eds.), North American sturgeons (pp. 111-117). Dordrecht, The Netherlands: Dr W. Junk Publisher.

Candrl, J. S., Papoulias, D. M., \& Tillitt, D. E. (2010). A minimally invasive method for extraction of sturgeon oocytes. North American Journal of Aquaculture, 72, 184-187. https://doi.org/10.1577/A09-006.1

DeLonay, A. J., Jacobson, R. B., Chojnacki, K. A., Braaten, P. J., Buhl, K. J., Eder, B. L., ...Wildhaber, M. L. (2016). Ecological requirements for pallid sturgeon reproduction and recruitment in the Missouri River-Annual report 2013. U.S. Geological Survey, Open-File Report 2015-1197, 99 pp.

DeLonay, A. J., Jacobson, R. B., Simpkins, D. G., Wildhaber, M. L., Reuter, J. M., Bonnot, T. W., ...Mack, M. J. (2009). Ecological requirements for pallid sturgeon reproduction and recruitment in the lower Missouri River a research synthesis 2005-08. U.S. Geological Survey, Scientific Investigations Report 2009-5201, Reston, Virginia.

Dryer, M. P., \& Sandvol, A. J. (1993). Pallid sturgeon recovery plan. Bismarck, ND: U.S. Fish and Wildlife Service.

Erickson, D. L., \& Webb, M. A. H. (2007). Spawning periodicity, spawning migration, and size at maturity of green sturgeon, Acipenser medirostris, in the Rogue River, Oregon. Environmental Biology of Fishes, 79, 255-268. https://doi.org/10.1007/s10641-006-9072-x

Feist, G., Schreck, C. B., Fitzpatrick, M. S., \& Redding, J. M. (1990). Sex steroid profiles of coho salmon (Oncorhynchus kisutch) during early development and sexual differentiation. General and Comparative Endocrinology, 80, 299-313. https://doi.org/10.1016/0016-6480(90)90174-K

Fitzpatrick, M.S., Van Der Kraak, G., \& Schreck, C. B. (1986). Profiles of plasma sex steroids and gonadotropin in coho salmon, Oncorhynchus kisutch, during final ovarian maturation. General and Comparative Endocrinology, 62, 437-451. https://doi.org/10.1016/0016-6480(86)90054-7

Fox, D. A., Hightower, J. E., \& Parauka, F. M. (2000). Gulf sturgeon spawning migration and habitat in the Choctawhatchee River System, Alabama-Florida. Transactions of the American Fisheries Society, 129, 811-826. https://doi.org/10.1577/15488659(2000)129<0811:GSSMAH>2.3.CO;2

Fuller, D. A., Jaeger, M. E., \& Webb, M. A. H. (2008). Spawning and associated movement patterns of pallid sturgeon in the lower Yellowstone River. Report prepared for the Upper Missouri River Basin pallid sturgeon Workgroup, Western Area Power Administration, and U.S. Army Corps of Engineers, Omaha, Nebraska.

Gerrity, P. C., Guy, C. S., \& Gardner, W. M. (2008). Habitat use of juvenile pallid sturgeon and shovelnose sturgeon with implications for waterlevel management in a downstream reservoir. North American Journal of Fisheries Management, 28, 832-843. https://doi.org/10.1577/ M07-061.1

Goodman, B. J., Guy, C. S., Camp, S. L., Gardner, W. M., Kappenman, K. M., \& Webb, M. A. H. (2013). Shovelnose sturgeon spawning in relation to varying discharge treatments in a Missouri River tributary. River Research and Applications, 29, 1004-1015. https://doi. org/10.1002/rra.2587

Guy, C. S., Treanor, H. B., Kappenman, K. M., Scholl, E. A., Ilgen, J. E., $\&$ Webb, M. A. H. (2015). Broadening the regulated-river management paradigm: A case history of the forgotten dead zone hindering pallid sturgeon recovery. Fisheries, 40, 6-14. https://doi. org/10.1080/03632415.2014.987236

Haxton, T. J., \& Cano, T. M. (2016). A global perspective of fragmentation on a declining taxon-The sturgeon (Acipenseriformes). Endangered Species Research, 31, 203-210. https://doi.org/10.3354/esr00767

Haxton, T. J., Sulak, K., \& Hildebrand, L. (2016). Status of scientific knowledge of North American sturgeons. Journal of Applied Ichthyology, 1-6, https://doi.org/10.1111/jai.13235 
Hildebrand, L., McLeod, C., \& McKenzie, S. (1999). Status of management of white sturgeon in the Columbia River in British Columbia, Canada: An overview. Journal of Applied Ichthyology, 15, 164-172. https://doi. org/10.1111/j.1439-0426.1999.tb00227.x

Holmquist, L. M. (2017). Reproductive ecology of hatchery-origin and wild pallid sturgeon in the Missouri River above Fort Peck Reservoir, Montana. Master's thesis, Montana State University, Bozeman.

Ireland, S. C., Beamesderfer, R. C. P., Paragamian, V. L., Wakkinen, V. D., \& Siple, J. T. (2002). Success of hatchery-reared juvenile white sturgeon (Acipenser transmontanus) following release in the Kootenai River, Idaho, USA. Journal of Applied Ichthyology, 18, 642-650. https ://doi.org/10.1046/j.1439-0426.2002.00364.x

Jordan, G. R., Heist, E. J., Braaten, P. J., DeLonay, A. J., Hartfield, P., Herzog, D. P., ... Webb, M. A. H. (2016). Status of knowledge of the pallid sturgeon (Scaphirhynchus albus Forbes and Richardson, 1905). Journal of Applied Ichthyology, 32, 191-207. https://doi.org/10.1111/jai.13239

Jordan, G. R., Klumb, R. A., Wanner, G. A., \& Stancill, W. J. (2006). Poststocking movements and habitat use of hatchery-reared juvenile pallid sturgeon in the Missouri River below Fort Randall Dam, South Dakota and Nebraska. Transactions of the American Fisheries Society, 135, 1499-1511. https://doi.org/10.1577/T05-201.1

Kappenman, K. M., Webb, M. A. H., \& Greenwood, M. (2013). The effect of temperature on embryo survival and development in pallid sturgeon Scaphirhynchus albus (Forbes \& Richardson 1905) andshovelnose sturgeon S. platorynchus (Rafinesque, 1820). Journal of Applied Ichthyology, 29, 1193-1203. https://doi.org/10.1111/jai.12301

Linares-Casenave, J., Van Eenennaam, J. P., \& Doroshov, S. I. (2002). Ultrastructural and histological observations on temperature-induced follicular ovarian atresia in white sturgeon. Journal of Applied Ichthyology, 18, 382-390. https://doi. org/10.1046/j.1439-0426.2002.00369.x

Papoulias, D. M., Delonay, A. J., Annis, M. L., Wildhaber, M. L., \& Tillett, D. E. (2011). Characterization of environmental cues for initiation of reproductive cycling and spawning in shovelnose sturgeon Scaphirhynchus platoryhncus in the Lower Missouri River, USA. Journal of Applied Ichthyology, 27, 335-342. https://doi. org/10.1111/j.1439-0426.2010.01657.x

Paragamian, V. L., \& Kruse, G. (2001). Kootenai River white sturgeon spawning migration behavior and predictive model. North American Journal of Fisheries Management, 21, 10-21. https://doi. org/10.1577/1548-8675(2001)021<0010:KRWSSM>2.0.CO;2

Paragamian, V. L., \& Wakkinen, V. D. (2002). Temporal distribution of Kootenai River white sturgeon spawning evens and the effect of flow and temperature. Journal of Applied Ichthyology, 18, 542-549. https:// doi.org/10.1046/j.1439-0426.2002.00391.x

Richards, R. R. (2011). Movement of Scaphirhynchus species in the Missouri River above Fort Peck Reservoir, Montana. Master's thesis. Montana State University, Bozeman.

Richards, R. R., Guy, C. S., Webb, M. A. H., Gardner, W. M., \& Jensen, C. B. (2014). Spawning related movement of shovelnose sturgeon in the Missouri River above Fort Peck Reservoir, Montana. Journal of Applied Ichthyology, 30, 1-13. https://doi.org/10.1111/jai.12336

Talbott, M. J., Van Eenennaam, J. P., Linares-Casanave, J., Doroshov, S. I., Guy, C. S., Struffenegger, P., \& Webb, M. A. H. (2011). Investigating the use of plasma testosterone and estradiol-17 $\beta$ to detect ovarian follicular atresia in farmed white sturgeon, Acipenser transmontanus. Aquaculture, 315, 283-289. https://doi.org/10.1016/j.aquaculture.2010.10.041

Talbott, M. J., \& Webb, M. A. H. (2014a). Determination of reproductive indices in wild hatchery-reared pallid sturgeon in the Missouri and Yellowstone Rivers Update, February 2014. Upper Basin Pallid Sturgeon Workgroup Annual Report, August 2013-May 2014.

Talbott, M. J., \& Webb, M. A. H. (2014b). Identification of reproductive indices and spawners in the captive pallid sturgeon population at Gavins Point National Fish Hatchery, 2013-2014 Annual Report.
Upper Basin Pallid Sturgeon Workgroup Annual Report, August 2013-May 2014.

Tyers, M. (2016). riverdist: River network distance computation and applications. R package version 0.13.0. https://CRAN.R-project.org/ package $=$ riverdist

USFWS (United State Fish and Wildlife Service) (2012). Biological procedure and protocols for researchers and managers handling pallid sturgeon (40 pp.). Denver, CO: Fish and Wildlife Service.

USFWS (United States Fish and Wildlife Service) (2000). Biological opinion on the operation of the Missouri River main stem reservoir system, operation and maintenance of the Missouri River bank stabilization and navigation project, and operation of the Kansas River reservoir system. Bismarck, ND: USFWS.

USFWS (United States Fish and Wildlife Service) (2003). Amendment to the biological opinion on the operation of the Missouri River main stem reservoir system, operation and maintenance of the Missouri River bank stabilization and navigation project, and operation of the Kansas River reservoir system. Minneapolis, MN: USFWS.

USFWS (United States Fish and Wildlife Service) (2014). Revised recovery plan for the pallid sturgeon (Scaphirhynchus albus) (115 pp.). Denver, CO: Fish and Wildlife Service.

Valdebenito, I., Paiva, L., \& Berland, M. (2011). Follicular atresia in teleost fish: a review. Archivos de medicina veterinaria, 43, 11-25. https://doi. org/10.4067/S0301-732X2011000100003

Van Eenennaam, J. P., Doroshov, S. I., Moberg, G. P., Watson, J. G., Moore, D. S., \& Linares, J. (1996). Reproductive conditions of the atlantic sturgeon (Acipenser oxyrinchus) in the Hudson River. Estuaries, 19, 769-777. https://doi.org/10.2307/1352296

Veshchev, P. V., \& Noikova, A. S. (1983). Reproduction of the stellate sturgeon, Acipenser stellatus (Acipenseridae), under regulated flow conditions in the Volga River. Journal of Ichthyology, 23, 42-50.

Veshchev, P. V., \& Noikova, A. S. (1988). Reproduction of sevryuga, Acipenser stellatus, in the lower Volga. Journal of Ichthyology, 28, 39-47.

Webb, M. A. H., \& Doroshov, S. I. (2011). Importance of environmental endocrinology in fisheries management and aquaculture of sturgeons. General and Comparative Endocrinology, 170, 313-321. https:// doi.org/10.1016/S0044-8486(01)00550-6

Webb, M. A. H., Maskill, P. A. C., \& Halvorson, L. J. (2016). Identification of reproductive indices and spawners in the captive pallid sturgeon population at Gavins Point National Fish Hatchery. Annual Report for the Upper Basin pallid sturgeon Workgroup.

Webb, M. A. H., Van Eenennaam, J. P., Crossman, J. A., \& Chapman, F. A. (2018). A practical guide for assigning sex and stage of maturity in sturgeons and paddlefish. Journal of Applied Ichthyology, 35(1), 169186. https://doi.org/10.1111/jai.13582

Webb, M. A. H., Van Eenennaam, J. P., Feist, G. W., Linares-Casenave, J., Fitzpatrick, M. S., Schreck, C. B., \& Doroshov, S. I. (2001). Effects of thermal regime on ovarian maturation and plasma sex steroids in farmed white sturgeon, Acipenser transmontanus. Aquaculture, 201, 137-171. https://doi.org/10.1016/S0044-8486(01)00550-6

Wildhaber, M. L., Holan, S. H., Davis, G. M., Gladish, D. W., DeLonay, A. J., Papoulias, D. M., \& Sommerhauser, E. K. (2011). Evaluating spawning migrations patterns and predicting spawning success of shovelnose sturgeon in the lower Missouri River. Journal of Applied Ichthyology, 27, 301-308. https://doi.org/10.1111/j.1439-0426.2010.01663.x

How to cite this article: Holmquist LM, Guy CS, Tews A, Trimpe DJ, Webb MAH. Reproductive ecology and movement of pallid sturgeon in the upper Missouri River, Montana. J Appl Ichthyol. 2019;35:1069-1083. https://doi.org/10.1111/ jai.13962 